\title{
Lung Keratinizing Squamous Cell
}

\section{Carcinoma}

National Cancer Institute

\section{Source}

National Cancer Institute. Lung Keratinizing Squamous Cell Carcinoma. NCI Thesaurus.

Code C136713.

A squamous cell lung carcinoma characterized by the presence of keratinization, pearl formation, and/or intercellular bridges. 